\title{
Tatalaksana Pasien Post Ventriculo Peritoneal (VP) Shunt et causa Meningitis disertai Aspirasi Pneumonia dan Gagal Napas di Ruang Rawat Intensif
}

\author{
Arief Kurniawan*), Ardi Zulfariansyah"**) \\ ${ }^{*}$ Departemen Anestesiologi dan Terapi Intensif Fakultas Kedokteran Universitas Ahmad Yani-RS TNI AD Dustira \\ Cimahi, ${ }^{* *}$ Departemen Anestesiologi dan Terapi Intensif Fakultas Kedokteran Universitas Padjadjaran-RSUD \\ Hasan Sadikin Bandung
}

\begin{abstract}
Abstrak
Ventriculo Peritoneal (VP) Shunt adalah tindakan operasi pemasangan kateter yang menghubungkan ventrikel otak dan rongga peritoneum. Tindakan VP Shunt bertujuan menurunkan tekanan intrakranial yang tinggi pada hidrosefalus. Pasien hidrosefalus akibat meningitis sering mengalami gagal napas akibat gangguan otak atau aspirasi pneumonia. Terapi ventilasi mekanik diperlukan sebelum, selama dan setelah operasi VP Shunt. Laporan kasus laki-laki 21 tahun datang ke rumah sakit karena gangguan kesadaran dan didiagnosis dengan meningitis. Pasien mengalami gagal napas akibat aspirasi pneumonia dan mendapat terapi ventilasi mekanik, kemudian menjalani operasi VP Shunt atas indikasi hidrosefalus komunikan. Induksi anestesi menggunakan fentanil dan propofol, pemeliharaan anestesi menggunakan sevofluran dan analgesi pascabedah menggunakan fentanil kontinyu. Berdasarkan pemeriksaan cairan serebrospinal pasien didiagnosis meningitis serosa akibat Tuberkulosis. Pasien mendapat terapi antibiotik empirik untuk aspirasi pneumonia dan antituberkulosis. Setelah kesadaran membaik dan weaning ventilator pasien dipindahkan dari ruang perawatan intensif.
\end{abstract}

Kata kunci: aspirasi pneumonia, meningitis serosa, ventrikulo peritoneal shunt, ventilasi mekanik

JNI 2020, 9 (2): 87-91

\section{Management Patient Post Ventriculo Peritoneal (VP) shunt et causa Meningitis with Pneumonia Aspiration and Respiratory Failure in ICU}

\begin{abstract}
Ventriculo Peritoneal (VP) Shunt is a surgery that connects the brain ventricles and the peritoneal cavity with a catheter. VP Shunt aims to reduce high intracranial pressure in hydrocephalus. Hydrocephalus patients due to meningitis often experience respiratory failure from brain disorder or pneumonia aspiration. Mechanical ventilation therapy is needed before, during and after VP Shunt surgery. Case report of 21-year-old came to the hospital with decreased of conciousness and diagnosed with meningitis. The patient experienced respiratory failure and received mechanical ventilation therapy in the intensive care unit. The patient underwent VP Shunt surgery for indications of communicant hydrocephalus. Induction of anesthesia used fentanyl and propofol, maintenance of anesthesia used sevoflurane and postoperative analgesia used continuous fentanyl. Based on the results of the examination of cerebrospinal fluid, the diagnosis leads to serous meningitis due to Tuberculosis bacteria. Empiric antibiotics therapy for aspiration pneumonia and antituberculosis were given even if no bacteria was found in the blood or cerebrospinal fluid. After improvement in clinical condition and weaning from mechanical ventilator, the patient discharge from the ICU and sent to the ward.
\end{abstract}

Key words: mechanical ventilation, pneumonia aspiration, serous meningitis, ventriculo peritoneal shunt

JNI 2020, 9 (2): 87-91 


\section{Pendahuluan}

Ventriculo Peritoneal (VP) Shunt adalah tindakan operasi pemasangan kateteryang menghubungkan ventrikel otak dan rongga peritoneum. Tindakan VP Shunt bertujuan menurunkan tekanan intrakranial yang tinggi pada hidrosefalus. Pasien hidrosefalus akibat meningitis sering mengalami gagal napas akibat gangguan otak atau aspirasi pneumonia. Penilaian perioperatif diperlukan untuk menentukan teknik anestesi dan tindakan pra dan pascaoperasi. Pasien yang mengalami gagal napas sebelum operasi memerlukan terapi ventilasi mekanik terlebih dahulu dan dilanjutkan sampai dengan perawatan pascaoperasi. ${ }^{1}$ Meningitis adalah infeksi cairan otak disertai radang yang mengenai piameter dan arakhnoid, serta menyebabkan nyeri kepala sampai gangguan kesadaran. ${ }^{2}$ Meningitis serosa ditandai dengan jumlah sel dan protein yang meninggi disertai cairan serebrospinal yang jernih. Penyebab meningitis serosa paling sering adalah kuman tuberculosis (TB) dan virus. ${ }^{3,4}$ Meningitis purulenta atau bakteri bersifat akut dan menghasilkan eksudat berupa pus. Insidensi meningitis berkisar $1-20$ per 100.000 penduduk dengan mortalitas 10-30 \%. Mortalitas yang tinggi dapat diturunkan dengan pengendalian tekanan intrakranial dan pemberian antibiotik yang tepat. ${ }^{5}$

Aspirasi pneumonia adalah infeksi paru yang terjadi setelah masuknya cairan, partikel eksogen, atau sekresi endogen ke dalam saluran napas bawah. ${ }^{6}$ Kebanyakan aspirasi pneumonia terjadi akibat aspirasi mikroorganisme dari rongga mulut atau nasofaring dan berhubungan dengan gangguan kesadaran dan reflek menelan. Aspirasi pneumonia berat ditandai dengan kegagalan pernapasan memerlukan terapi antibiotik dan ventilasi mekanik. Ventilasi mekanik berperan meningkatkan pengambilan oksigen dan pembuangan karbon dioksida pada gagal napas, serta mengurangi resiko hipoksia otak yang memperberat gangguan kesadaran. ${ }^{7}$ Laporan kasus ini bertujuan memaparkan penatalaksanaan perioperatif VP Shunt pada pasien yang mengalami gagal napas dan memerlukan ventilasi mekanik sebelum, selama dan setelah operasi.

\section{Kasus}

\section{Anamnesa}

Seorang laki-laki umur 21 tahun datang ke Rumah Sakit Hasan Sadikin Bandung pada tanggal 16 Oktober 2019 dengan keluhan utama penurunan kesadaran yang terjadi empat jam sebelum masuk rumah sakit. Pasien mengeluh nyeri kepala selama satu minggu disertai demam. Riwayat terapi atau kontak dengan pasien TB disangkal. Pada hari kedua perawatan pasien mengalami gagal napas ditandai laju pernapasan $38 \mathrm{x} /$ menit dan work of breathing. Gagal napas diduga akibat aspirasi pneumonia kemudian mendapat terapi ventilasi mekanik di ruang perawatan intensif dengan mode Pessure Support 10 PEEP $6 \mathrm{FiO}_{2}$ 50\% laju pernapasan $23 \mathrm{x} /$ menit. Pasien diberi sedatif midazolam $2,5 \mathrm{mg} / \mathrm{jam}$ dan analgetik fentanil 25 $\mathrm{mcg} / \mathrm{jam}$. Antibiotik empirik ceftazidim 1 gram per 8 jam dan levofloksasin $750 \mathrm{mg}$ per hari diberikan untuk mengatasi infeksi.

\section{Pemeriksaan Fisik}

Pada pemeriksaan fisik tampak sakit berat, tekanan darah 120/70 $\mathrm{mmHg}$, nadi $96 \mathrm{x} / \mathrm{mnt}$, laju pernapasan $20 \mathrm{x} /$ menit, suhu $38,7{ }^{\circ} \mathrm{C}$, GCS: E4M5V4, kaku kuduk: (+), Kernig (+), Lasegue $(+)$ dan kekuatan motoris $4 / 5$.

\section{Pemeriksaan Penunjang}

Hasil pemeriksaan darah menunjukkan $\mathrm{Hb} 14 \mathrm{~g} /$ dl, leukosit $13.200 / \mu 1$, trombositt $385.000 / \mu 1$, hematokrit 38,7\%, LED $22 \mathrm{~mm} / \mathrm{jam}$ dan hasil pemeriksaan foto dada normal.

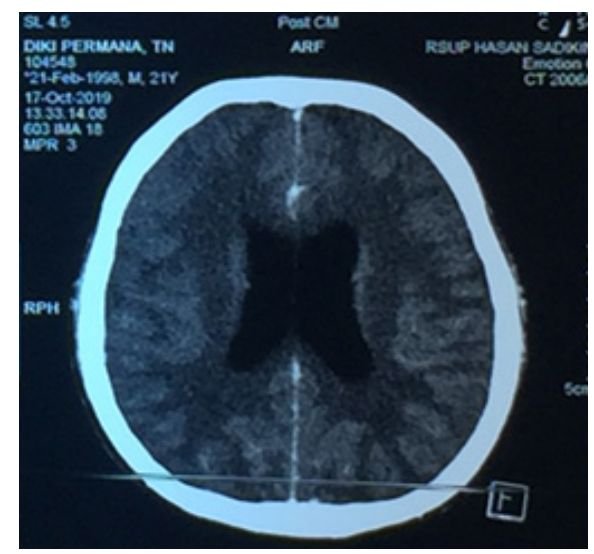

Gambar 1. CT Kepala Menunjukkan Hidrosefalus Komunikan 
Pasien didiagnosis meningitis dengan kemungkinan meningitis serosa atau purulenta. CT Scan kepala menunjukkan penebalan meningeal mengisi tentorium serebeli, sisterna basalis, falks serebri dan sulci giri kortikalis lobus parietalis bilateral disertai hidrosefalus komunikan menyokong suatu meningitis (Gambar 1). Pasien direncanakan operasi VP Shunt. Hasil pemeriksaan rontgen dada menunjukkan peningkatan corakan bronkovaskuler pada kedua lapang paru (Gambar 2).

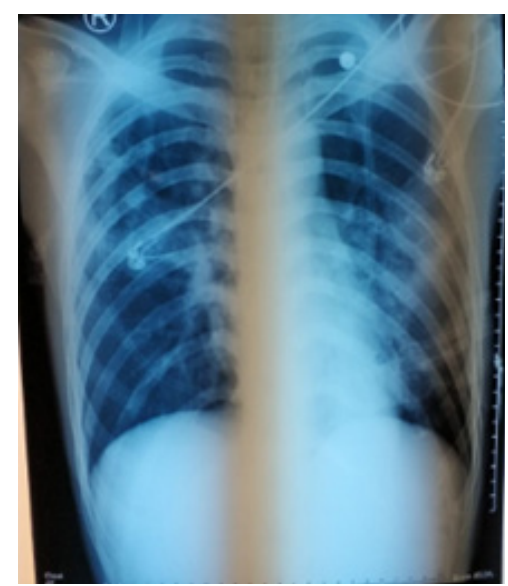

Gambar 2. Corakan Bronkovaskuler pada Rontgen Dada

\section{Pengelolaan Anestesi}

Pasien menjalani operasi VP Shunt atas indikasi hidrosefalus komunikan. Selama transfer dari ICU ke kamar bedah, pasien dalam kondisi terintubasi dan diberi bantuan napas dengan ambubag mengikuti napas pasien dengan oksigen $5 \mathrm{~L} /$ menit. Induksi intravena menggunakan fentanil $50 \mathrm{mcg}$, propofol $100 \mathrm{mg}$ dan relaksasi menggunakan rokuronium $50 \mathrm{mg}$. Pemeliharaan anestesi oksigen : udara $=2 \mathrm{~L} /$ menit: $2 \mathrm{~L} /$ menit, sevofluran 1-2 volume $\%$. Ventilator diatur dengan volume tidal $300 \mathrm{ml}$, pernapasan $12 \mathrm{kali} / \mathrm{menit}$, I $: E=1: 2$. Operasi dilakukan selama 1 jam. Pada akhir operasi diberikan bolus fentanil $50 \mathrm{mcg}$ dilanjutkan pemberian kontinyu $25 \mathrm{mcg} / \mathrm{jam}$.

\section{Pengelolaan Pascabedah di ICU}

Terapi ventilator, sedatif dan analgesi dilanjutkan di ICU. Hasil pemeriksaan cairan serebrospinal yang diperoleh saat operasi mengarahkan diagnosis pada meningitis serosa yaitu warna jernih, Nonne dan Pandy negatif, protein 37,7 mg/ dl, glukosa $35 \mathrm{mg} / \mathrm{dl}$, jumlah sel 27 sel/uL 100\% mononuklear, pemeriksaan gram dan kultur tidak ditemukan kuman. Pada hari ketiga perawatan ICU dilakukan pungsi lumbal dengan hasil pemeriksaan cairan serebrospinal warna jernih, protein $1830 \mathrm{mg} / \mathrm{dl}$, glukosa $29 \mathrm{mg} / \mathrm{dl}$, jumlah sel 481 sel/uL 100\% mononuklear dan tidak ditemukan kuman. Berdasarkan pemeriksaan cairan serebrospinal, diagnosis mengarah pada meningitis tuberkulosis. Pasien diterapi antituberkulosis rifampisin $900 \mathrm{mg}$, INH 300 $\mathrm{mg}$, pirazinamid $1500 \mathrm{mg}$ dan ethambutol 1000 mg. Pada hari kesepuluh perawatan ruang ICU pasien kesadaran membaik dan berhasil weaning ventilator kemudian pasien dipindahkan ke ruang perawatan biasa dengan terapi antituberkulosis dilanjutkan. Data pengamatan tanda vital pasien dapat dilihat pada Gambar 3.

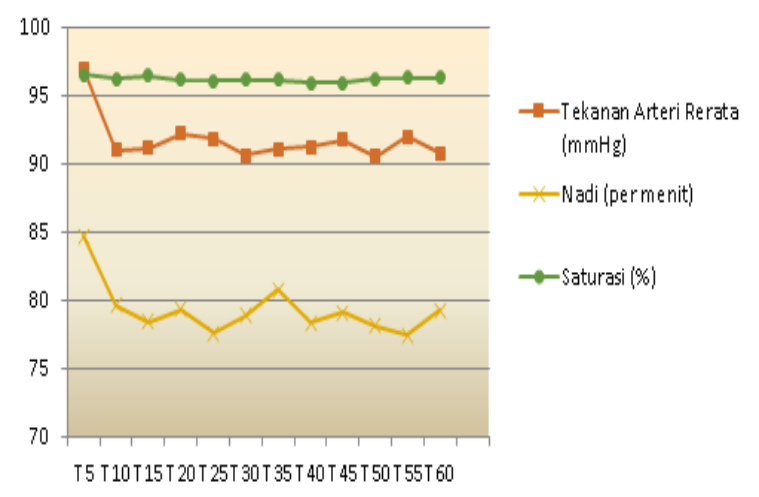

Gambar 3. Pengamatan Tanda Vital selama Operasi

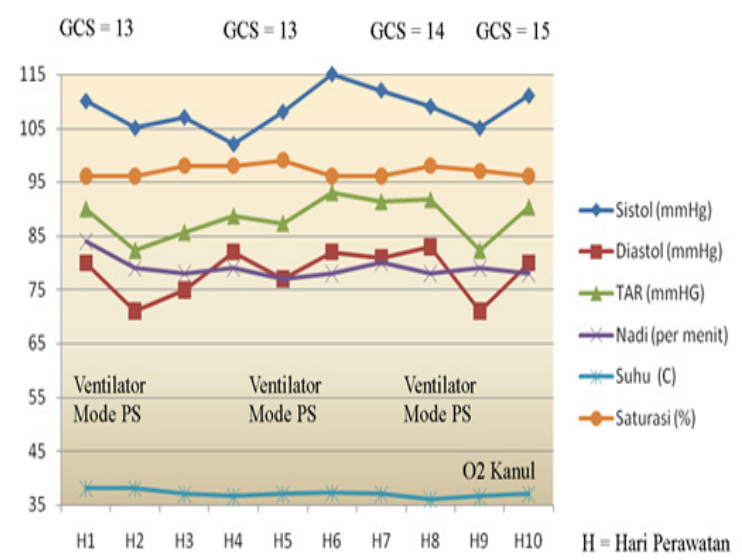

Gambar 4. Pengamatan Tanda Vital di ICU 


\section{Pembahasan}

Berdasarkan penilaian preoperatif pasien mengalami gagal napas ditandai laju pernapasan $38 \mathrm{x} /$ menit, work of breathing dan peningkatan corakan bronkovaskuler paru. Gagal napas diduga akibat pneumonia kemudian pasien mendapat terapi ventilasi mekanik dengan pemeliharaan sedatif dan analgetik. Kondisi ventilasi pasien harus tetap dijaga dengan pemberian sedatif dan analgetik dilanjutkan saat transfer pasien dari ruang perawatan ke kamar operasi. Bantuan pernapasan dengan ambubag mengikuti napas pasien dilanjutkan dengan penyambungan pipa endotrakheal ke sirkuit mesin anestesi. Teknik anestesi umum merupakan teknik anestesi pilihan pada pasien yang mengalami gagal napas preoperatif dengan kontrol pernapasan. Pada perawatan pascaoperasi terapi ventilasi mekanik dilanjutkan dengan pemberian sedatif dan analgetik.

Pneumonia didiagnosis berdasarkan kriteria klinis yaitu demam, hipoksia, lekositosis dan peningkatan infiltrat paru. Bentuk pneumonia bukan merupakan pneumonia komunitas (CAP) yang terjadi sebelum perawatan rumah sakit ataupun pneumonia nosokomial (HAP) yang terjadi setelah 48 jam perawatan. Namun pneumonia yang terjadi kurang dari 48 jam perawatan dan menimpa pasien gangguan kesadaran dapat dianggap sebagai aspirasi pneumonia yang merupakan bagian dari CAP. ${ }^{8}$ Mengacu pada guideline CAP 2019 pasien diatas dapat dikelompokkan pada CAP berat dengan satu kriteria mayor berupa gagal napas yang memerlukan ventilasi mekanik dan tiga kriteria minor berupa takipnu, disorientasi dan peningkatan bronkovaskuler. Bantuan napas menggunakan ventilator pada pasien di atas dengan mode Pressure Support, Positive End Expiratory Pressure (PEEP) 5, volume tidal $357 \mathrm{ml}$, sesuai untuk ARDS ringan sebagaimana algoritma manajemen ARDS Guidline 2019.9 Terapi antibiotik empirik saat masuk ICU sesuai dengan guidline aspirasi pneumonia Infectious Disease Society of America (IDSA) 2016 menggunakan sefalosporin generasi III kombinasi dengan quinolon. Dengan pertimbangan aspirasi pneumonia mendapatkan ventilasi mekanik dan setelah terapi antibiotik tiga hari tetapi masih terjadi peningkatan lekositosis maka diganti sefalosporin generasi IV yang memiliki cakupan spektrum lebih luas. Terapi antibiotik empirik menggunakan antibiotik kombinasi (cefotaksim+ levofloksasin) sesuai pada kelompok terapi Severe Inpatient Pneumonia menggunakan Standard Regimen. Pada hari ketiga, cefotaksim diganti dengan cefepim sesuai pada kelompok terapi kemungkinan infeksi Pseudomonas aerugenosa. ${ }^{9}$

Pasien di atas didiagnosis meningitis serosa berdasarkan gejala dan tanda meningitis (demam, kaku kuduk, hemiparese, Kernieg, lekositosis) disertai temuan warna CSS yang jernih. Hasil pemeriksaan CT-scan kepala didapatkan gambaran hidrosefalus sehingga tindakan pungsi lumbal untuk diagnosis meningitis ditunda setelah operasi VP-shunt. Hasil pemeriksaan CSS pertama belum bisa menentukan penyebab meningitis serosa apakah tuberkulosis atau virus. Pada pasien ini belum diberi antibiotik empirik meskipun guidline meningitis menyebutkan antibiotik perlu diberikan segera setelah pasien tiba di rumah sakit dengan diagnosis meningitis tanpa menunggu hasil pemeriksaan CSS. $^{10}$ Hasil pemeriksaan CSS dari pungsi lumbal didapatkan protein $1830 \mathrm{mg} / \mathrm{dl}$, jumlah sel $481 \mathrm{sel} / \mathrm{uL}(\mathrm{MN})$ dan glukosa $29 \mathrm{mg} / \mathrm{dl}$ lebih mengarah ke meningitis TB dibanding meningitis virus, meskipun pada pemeriksaan kultur tidak ditemukan kuman. Terapi dengan regimen antituberkulosis Rifampisin INH Pirazinamid Etambutol (RHZE) perlu diberikan pada kasus seperti ini. ${ }^{11}$ Setelah terapi antibiotik ganda kombinasi dengan antituberkulosis pasien mengalami perbaikan kondisi (peningkatan GCS, weaning ventilator) dan berhasil dilakukan ekstubasi. Pasien pindah ke ruang perawatan biasa dengan terapi antituberkulosis perlu dilanjutkan. Perpaduan terapi ventilasi mekanik, VP-shunt dan antibiotik memberikan hasil yang baik pada pasien ini. Ventilasi mekanik berperan meningkatkan pengambilan oksigen dan pembuangan karbondioksida pada gagal napas. Ventilasi yang normal mengurangi resiko hipoksia otak dan peningkatan tekanan intrakranial yang memperberat gangguan kesadaran. 


\section{Simpulan}

Telah dilaporkan satu kasus pasien hidrosefalus komunikans akibat meningitis serosa disertai aspirasi pneumonia dan gagal napas yang menjalani tindakan $V P$ shunt. Dengan pemberian terapi empirik, antibotik dan penggunaan ventilasi mekanik dan observasi ketat di ICU pasien mengalami perbaikan kondisi dan dapat dilepas dari bantuan ventilasi mekanik.

\section{Daftar Pustaka}

1. Jamjoom AAB, Joannides AJ, Poon MT, Chari A, Zaben M, Abdulla MAH, Roach J, Glancz LJ, et al. Prospective, multicentre study of external ventricular drainage-related infections in the UK and Ireland. J Neurol Neurosurg Psychiatry. 2018; 89(2): 120-26.

2. McIntyre PB, O'Brien KL, Greenwood B, van de Beek D. Effect of vaccines on bacterial meningitis worldwide. Lancet 2012; 380: 1703-11.

3. Brouwer MC, Tunkel AR, van de Beek D. Epidemiology, diagnosis, and antimicrobial treatment of acute bacterial meningitis. Clin Microbiol Rev 2010; 23: 467-92.

4. Van de Beek D, Brouwer MC, Thwaites GE, Tunkel AR. Advances in treatment of bacterial meningitis. Lancet 2012; 380: 1693-702.

5. Bijlsma MW, Bekker V, Brouwer MC, Spanjaard L, van de Beek D, van der Ende A. Epidemiology of invasive meningococcal disease in the Netherlands, 1960-2012: an analysis of national surveillance data. Lancet Infect Dis 2014; 14: 805-12.

6. Martin NG, Sadarangani M, Pollard AJ,
Goldacre MJ. Hospital admission rates for meningitis and septicaemia caused by Haemophilus influenzae, Neisseria meningitidis, and Streptococcus pneumoniae in children in England over five decades: a population-based observational study. Lancet Infect Dis 2014; 14: 397-405.

7. Koopmans MM, Brouwer MC, Bijlsma MW, Bovenkerk S, Keijzers W, van der Ende A, et al. Listeria monocytogenes sequence type 6 and increased rate of unfavorable outcome in meningitis: epidemiologic cohort study. Clin Infect Dis 2013; 57: 247-53.

8. Metlay JP, Waterer GW, Long AC, Anzueto A, Brozek J, Crothers K, et al. Diagnosis and treatment of adults with community-acquired pneumonia, an official clinical practice guideline of the American Thoracic Society and Infectious Diseases Society of America. Am J Respir Crit Care Med 2019; 200(7): $45-67$.

9. Papazian L, Aubron C, Brochard L, Chiche JD, Combes A, Dreyfuss D, et al. Formal guidelines: management of acute respiratory distress syndrome. Ann Intensive Care 2019; 9: 69-87.

10. Van de Beek D, Cabellos C, Dzupova P, Esposito S, Klein M, Kloek AT, Leib SL, et al. ESCMID guideline: diagnosis and treatment of acute bacterial meningitis. Clin Microbiol Infect 2016; 22: S37-S62.

11. McGill F, Heyderman RS, Michael BD, Defres S, Beeching NJ, Borrow R, et al. The UK joint specialist societies guideline on the diagnosis and management of acute meningitis and meningococcal sepsis in immunocompetent adults. J Infect 2016; 20 : $1-34$. 